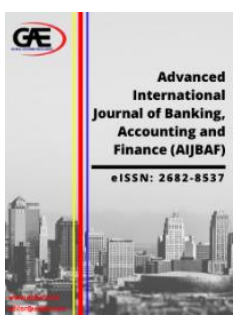

\author{
ADVANCED INTERNATIONAL JOURNAL OF \\ BANKING, ACCOUNTING AND FINANCE \\ (AIJBAF) \\ WWW.aijbaf.com
}

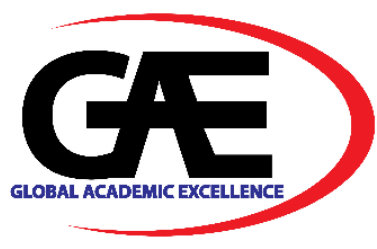

\title{
HOW SALES PROMOTION CAN EFFECT ON CONSUMER'S PURCHASE DECISIONS
}

\author{
Gugum Gumilang Wirakanda ${ }^{1}$, Dematria Pringgabayu ${ }^{2 *}$, Suci Fika Widyana ${ }^{3}$ \\ $1 \quad$ Politeknik Pos Indonesia \\ Email: gumilanggugum13@poltekpos.ac.id \\ 2 Politeknik Pajajaran ICB Bandung, Indonesia \\ Email: dematria.pringgabayu@ poljan.ac.id \\ 3 Politeknik Pos Indonesia \\ Email: fika.bharata@poltekpos.ac.id \\ * Corresponding Author
}

\section{Article Info:}

\section{Article history:}

Received date: 06.04.2021

Revised date: 11.04.2021

Accepted date: 02.05.2021

Published date: 15.06.2021

\section{To cite this document:}

Wirakanda, G. G., Pringgabayu, D., \& Widyana, S. F. (2021). How Sales Promotion Can Effects on Consumer's Purchase Decisions. Advanced International Journal of Banking, Accounting, and Finance, 3 (7), 59-71.

DOI: $10.35631 /$ AIJBAF.37005

This work is licensed under $\underline{\mathrm{CC} B Y} 4.0$

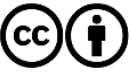

Abstract:

The research aims are to determine customer ratings of Sales Promotion conducted by Blibli.com, determine purchasing decisions made by Blibli.com customers, and determine the effect of Sales Promotion variables on Purchasing Decisions. The population in this research is Blibli.com customers with a total sample of 100 respondents using non-probability sampling methods, namely the accidental sampling technique. This research uses descriptive analysis techniques and simple regression. The results of this study indicate that customer ratings of sales promotion conducted by Blibli.com are "good". Based on the results of simple regression analysis and hypothesis testing shows that the sales promotion variable has a positive and significant effect of $71.1 \%$ on the purchase decision variable.

Keywords:

Sales Promotion, Purchasing Decision

\section{Introduction}

The development of information technology in the era of globalization is very rapid and affects the world of business and industry, even influencing social life. Technology has gradually improved its functions, applications (software) and usage, following the development of an 
Volume 3 Issue 7 (June 2021) PP. 59-71

DOI 10.35631/AIJBAF.37005

increasingly large flow of information that is easily accessible to the public. The significant development of information technology requires the provision of hardware (computers, servers) as the main support for the proper flow of information. The relevance of the development of technology and information is meant to make the internet the main backbound. The Industrial Age is getting more rapidly due to the flow of information that is marked by direct customer needs which are individual or mass products with on-line services and records in all fields. Therefore the internet is now a basic necessity for most people besides the need for food, clothing and shelter. Internet media has also become a means of promoting products that have very good prospects today, where through the internet media sellers can reach consumers widely. Even now that the internet has entered various parts of the country, people who live far from cities can take advantage of internet facilities. Business development through internet media is increasing day by day, in line with the increasing number of internet users in the world, especially in Indonesia.

From the survey data of internet users in Indonesia, it can be seen that internet users in Indonesia have reached 88.1 million. When compared with the total population of Indonesia, which is 252.4 million people, it can be said that internet users in Indonesia reach $34.9 \%$.

Blibli.com uses various kinds of marketing mix, one of which is Sales Promotion. Sales promotions are a variety of short-term incentives to encourage trial or purchase of a product or service including customer promotions (such as samples, coupons, and premiums), trade promotions (such as advertising and benefit displays), and business and sales force promotions (such as contests for sales reps). ). Sales Promotion implemented by Blibli.com aims to build good relationships with consumers, not just creating temporary, short-term sales increases. By implementing the Blibli.com Sales Promotion to strengthen product positions and build longterm relationships with consumers. The following is a table of the implementation of the Blibli.com Sales Promotion in 2019.

Table 1: Implementation of Blibli.com Sales Promotion

\begin{tabular}{ll}
\hline Sales Promotion that is applied & Explanation \\
\hline Coupon & Lottery program for the purchase of certain \\
& units \\
Conducted in the form of flash sales 3 times & $\begin{array}{l}\text { a day. Discounts are also made on holiday } \\
\text { celebrations } \\
\text { Combining two products or certain } \\
\text { pundling }\end{array}$ \\
& products in a sales package \\
\hline
\end{tabular}

(Source: Sales Blibli.com)

Based on the table above, Blibli.com always offers attractive programs in the implementation of Sales Promotion to attract consumer attention so that it can lead to purchasing decisions for consumers and will have an impact on sales results that will be received by Blibli.com. Blibli.com sales data for the period January to June 2019 shows that the highest sales occurred in June, amounting to 40,434 units, this happened because of the high demand from consumers in the month of Ramadan. Meanwhile, sales in February experienced a decline where there were 445 units of sales target that had not been achieved and in April, sales again decreased where there were 995 sales targets that were not achieved. This is a problem for the company, Copyright (C) GLOBAL ACADEMIC EXCELLENCE (M) SDN BHD - All rights reserved 
Volume 3 Issue 7 (June 2021) PP. 59-71

DOI 10.35631/AIJBAF.37005

if the decline in sales that do not reach the sales target is allowed to have a bad impact on the company. The decline in sales targets that occurs can be due to a lack of information conveyed to consumers about the products being offered. The delivery of this information can be done in various ways, one of which is by using sales promotions.

It can be concluded that the sales promotion carried out by Blibli.com needs to be further improved. This can be seen based on the number of unit sales in April that have not reached the sales target. This situation can be caused due to a lack of information about the advantages of the category products offered that are delivered to consumers. Based on the problems described above, in this study it was decided to take the title "The Effect of Sales Promotion on Purchasing Decisions at Blibli.com."

\section{Literature Review}

\section{Sales Promotion}

Kotler \& Keller (2012: 518), suggest that sales promotion is a short-term incentive to encourage sales of products or services.

According to Kotler (2014: 362) "Sales Promotion is short term incentives to encourage the purchase or sale of products or service" which means that sales promotion is a short term intensive to increase the passion to buy goods or services.

According to Neha \& Manoj (2013: 112) sales promotion is an activity or material that offers various parties a motivational boost to make purchases. The incentives that add value or intensify to the product can be in the form of coupons, lottery prizes, or guaranteed returns.

Kotler \& Armstrong (2016: 520) states that there are several dimensions of sales promotion that can be measured:

1) Coupons

2) Rebates (Price Discounts)

3) Price Packs / cents-off-deals

\section{Purchase Decision}

According to Swastha \& Irawan (2008: 105-112), purchasing decisions are consumers' understanding of the wants and needs of a product by assessing and existing sources by setting purchase objectives and identifying alternatives so that decision makers.

According to Basri et al (2016), the starting point for understanding buyer behavior is a stimulation model for the response of marketing and environmental stimuli to the buyer's awareness. The characteristics of the buyer and the decision-making process will give rise to certain purchasing decisions.

According to Putri (2017: 13) the decision to purchase goods or services often involves two or more parties and the decision-making process varies greatly. 
Volume 3 Issue 7 (June 2021) PP. 59-71

DOI 10.35631/AIJBAF.37005

Stages of the Purchasing Decision Process According to Kotler \& Armstrong (2016: 176-178)

1) Problem Recognition.

The buyer process begins with the introduction of a problem or need. The buyer realizes a difference between the real situation and the state he wants. The need can be driven by stimuli from within the buyer or from outside. Marketers need to know various things that can drive certain needs or interests in consumers.

2) Information Search

A consumer who is starting to be intrigued may or may not be looking for more information. If the consumer's impulse is strong, and an object that satisfies that need is available, the consumer will buy that object. If not, the consumer's need remains in his memory and does not seek further information regarding that need.

3) Evaluation of Alternatives

After searching for as much information as possible about many things, then consumers must make an assessment of some of the available alternatives and determine their next steps.

4) Purchase Decision

After the initial stages have been carried out, now it is time for the buyer to decide whether to buy or not if the decision is related to the type of product, brand, quality and so on.

5) Postpurchase Behavior

After buying a product, consumers will experience some level of satisfaction or no satisfaction. There is a possibility that the buyer has dissatisfaction after making a purchase, because maybe the price of the item is considered too expensive, or maybe because it is not in accordance with previous and other wishes.

\section{Hypothesis}

Sugiyono (2017: 63) states that the hypothesis is a temporary answer to the formulation of research problems, where the formulation of the problem is stated in the form of a question sentence. It is said temporarily because the answers given are only based on relevant theories, not based on empirical facts obtained through data collection or questionnaires. Based on the description above, the hypotheses in this study is:

\section{Ha: There is a significant effect of sales promotion on purchasing decisions}

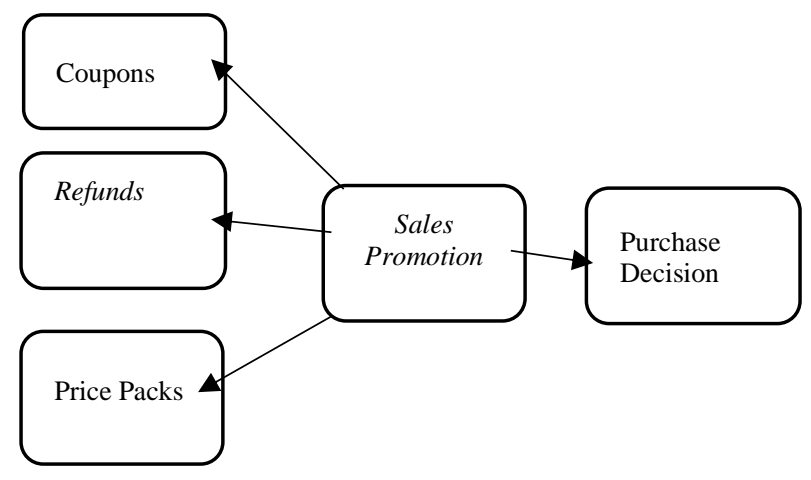

Figure 1. Research Paradigm 


\section{Research Method}

\section{Research Design}

The design of the research in the process of preparing this report uses descriptive methods, data retrieval techniques with questionnaires. According to Sugiyono (2017:19) descriptive method is a method used to describe the state or value of one or more intervals independently. This study uses simple linear regression data analysis to know the influence of variable sales promotion (independent) on purchasing decisions.

\section{Population and Samples}

Population is a generalized area consisting of objects that have certain characteristics (Sugiyono, 2017:80) in the population research taken are customers of Blibli.com whose number is unknown. Sampling size determination using Lemeshow formula as follows:

$$
\mathrm{n}=\mathrm{z} 2 \mathrm{P}(1-\mathrm{P})
$$

$\mathrm{d} 2$

Description:

$\mathrm{n}=$ number of samples

$\mathrm{z}=1.96$

$\mathrm{P}=$ maximum estimate $(0.5)$

$\mathrm{D}=\operatorname{alpha}(5 \%$ or $10 \%)$

Thus the number of samples taken as many as 100 respondents. Sampling is done using nonprobability sampling method with incidental sampling technique. Incidental sampling is a sampling technique based on coincidence, which is who accidentally meets with researchers.

\section{Data Collection Techniques}

The data collection technique used in this study conducted a survey through a questionnaire in which the questionnaire was distributed to 100 respondents and then answered by repsonden. Questionnaire is a data collection technique that is done by giving a set of questions or written statements to respondents to answer (Sugiyono, 2017: 225). The questionnaire used in this study was by interval scale method.

\section{Data Analysis Techniques}

\section{Descriptive Analysis}

In this study descriptive analysis was used in deciscripting the response characteristics of respondents and describing free variables (Sales Promotion) and bound variables (Purchase Decisions)

\section{Correlation Analysis}

Correlation analysis in this study is used to measure the strength of a weak relationship between a free variable and a bound variable. This method of measurement is used because the data used is ordinal (has a sequence, strongly agrees, agrees, hesitates, disagrees and strongly agrees)

According to Sugiyono (2017:170) guidelines to provide interpretation of correlation coefficients as follows: 


$$
\begin{aligned}
& 0.00-0.199=\text { Very Low } \\
& 0.20-0.399=\text { Low } \\
& 0.40-0.599=\text { Medium } \\
& 0.60-0.799=\text { Strong } \\
& 0.80-1.00=\text { Very Strong }
\end{aligned}
$$

\section{Simple Regression Analysis}

This analysis aims to find out how much of an independent variable affects dependent variables. Regression is used to measure the magnitude of the influence of free variables on bound variables and predict bound variables using free variables. The regression analysis used in this study was a simple linear regression. The equation of simple regression with one predictor according to Sugiyono (2017:188) is formulated as follows:

$$
Y^{\prime}=a+b X
$$

\section{Coefficient of Determination}

The coefficient of determination measures the percentage of influence of all independent variables in the regression model on their dependent variables. The magnitude of the coefficient of determination is a percentage, which indicates the percentage variation in dependent variable values that can be described by the regression model. When the coefficient of determination in a small (near-zero) regression model means less influence of all independent variables on their dependent variables. If the value of $\mathrm{R} 2$ is small it means the ability of all independent variables in describing dependent variables is very limited. Conversely, when R2 gets closer to $100 \%$ it means that all independent variables in the model provide almost all the information needed to predict their independent variables (Beins, 2017:195). Here's the formula of the coefficient of determination:

$$
\mathrm{KD}=\mathrm{r} 2 \times 100 \%
$$

\section{Hypothesis Test}

Statistical calculations are called statistically significant if the statistical test value is in a critical area (the area where Ho was rejected). On the contrary, it is insignificant when its statistical test scores are in the area where Ho was received (Ghozali, 2016:97)

\section{Results Of Research and Discussion}

\section{Validity Test}

Table 2 Validity Test Results

\begin{tabular}{lcc}
\hline Statement & $\begin{array}{c}\text { Corrected } \\
\text { Item-Total } \\
\text { Correlation }\end{array}$ & $\begin{array}{c}\text { Squared } \\
\text { Multiple } \\
\text { Correlation }\end{array}$ \\
\hline $\begin{array}{l}\text { Coupon Rate } \\
\begin{array}{l}\text { Level of Consumer } \\
\text { Interest }\end{array}\end{array}$ & .555 & Valid \\
$\begin{array}{l}\text { Refunds Offer Rate } \\
\text { Refunds Compliance } \\
\text { Rate }\end{array}$ & .671 & Valid \\
\hline
\end{tabular}


Volume 3 Issue 7 (June 2021) PP. 59-71

$\begin{array}{lll}\text { Price Pack Frequency } & .685 & \text { Valid } \\ \text { Price Pack Variations } & .673 & \text { Valid } \\ \text { Level of Need } & .742 & \text { Valid } \\ \text { Information Search } & .472 & \text { Valid } \\ \text { Buyer Response } & .726 & \text { Valid } \\ \text { Purchase Decision } & .675 & \text { Valid } \\ \text { Pacsa Purchase } & .555 & \text { Valid }\end{array}$

DOI 10.35631/AIJBAF.37005

(Source: IBM SPSS Statistics)

Based on the results of validity test using SPSS 22.0 regarding the accuracy of statement indicators in the questionnaire resulted in corrected item-total correlation with a large $>0.3$, according to Sugiyono (2017:198). If the correlation is positive and the magnitude is 0.3 and above then it is declared valid. From the test results above, it can be concluded, that coupon indicators, refunds (discounts) and price packs (price packs), problem recognition, information search, alternative evaluation and purchase decisions are declared valid for further analysis.

\section{Reliability Test}

Table 3 Reliability Test Variables $X$ and $Y$

\begin{tabular}{cccc}
\hline Variable & $\begin{array}{c}\text { Cronbach } \\
\text { s Alpha }\end{array}$ & $\begin{array}{c}\text { Cronbach's Alpha Based on } \\
\text { Standardized Items }\end{array}$ & $\begin{array}{c}\text { N of } \\
\text { Items }\end{array}$ \\
\hline $\mathrm{X}$ & .845 & .851 & 10 \\
$\mathrm{Y}$ & .789 & .788 & 5 \\
\hline
\end{tabular}

(Source: Primary Data Processed, 2021)

Based on the table above it can be seen that the value of Cronbach's alpha is 0.845 and 0.789 is above 0.6 so the questionnaire used in this study is reliable.

\section{Normality Test}

Table 4. Data Normality Test

\begin{tabular}{llr}
\hline & & $\begin{array}{r}\text { Unstandardized } \\
\text { Residual }\end{array}$ \\
\hline $\mathrm{N}$ & & 100 \\
Normal & Mean & .0000000 \\
Parameters ${ }^{\mathrm{a}, \mathrm{b}}$ & Std. Deviation & 2.24157421 \\
Most Extreme & Absolute & .102 \\
Differences & Positive & .102 \\
& Negative & -.101 \\
Test Statistic & & .102 \\
Asymp. Sig. (2-tailed) & $.013^{\mathrm{c}}$
\end{tabular}

(Source: SPSS Program Output) 
Volume 3 Issue 7 (June 2021) PP. 59-71

DOI 10.35631/AIJBAF.37005

Normality tests are necessary because to perform other variable tests assuming that residual values follow normal distribution. From the Normality Test table above is obtained the number Of Normality or Asymp Sig (2-tailed). Nilia is compared to 0.05 or uses a significance level of $5 \%$. Based on table 4.3 it can be read that the probability number or Asymp Sig (2-tailed) of 0.13 is greater than 0.05 , so it can be concluded that the residual value is normally distributed.

\section{Descriptive Analysis}

\section{Sales Promotion Continuum Line}

\begin{tabular}{l|l|l|l|l|}
$\begin{array}{l}\text { Very } \\
\text { Not } \\
\text { Good }\end{array}$ & $\begin{array}{l}\text { Not } \\
\text { Good }\end{array}$ & Good & $\begin{array}{l}\text { Very } \\
\text { Good }\end{array}$ & \\
\hline & & & & \\
600 & 1200 & $1800 \quad \mathbf{1 8 9 4}$ & 2400 & 3000
\end{tabular}

Figure 2 Variable Continuum Line $\mathrm{X}$

(Source: Processed Author, 2021)

A continuum line is a line used to analyse, measure, and show how much of a variable's strength level is being studied, according to the instrument used. Based on the picture above obtained the score for the variable sales promotion is 1894 which is at a good interval. This illustrates that sales promotion is good.

\section{Purchase Decision Continuum Line}

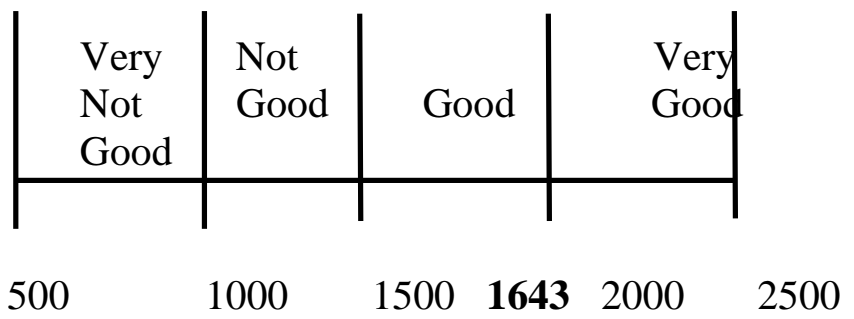

(Source: Processed Author, 2021)

Figure 3 Variable Continuum Line $Y$

Based on the picture above obtained the score for the variable sales promotion is 1643 which is at a good interval. This illustrates that sales promotion is good.

\section{Correlation Analysis}

This analysis is intended to determine the relationship between variable $\mathrm{X}$ (sales promotion) and variable $\mathrm{Y}$ (purchase decision). The goal is to make sure between the two variables whether the level of relationship is very strong, strong, strong enough, low, very low. 
Table 5 Correlation

\begin{tabular}{ccc}
\hline & $\begin{array}{c}\text { Sales } \\
\text { Promotion }\end{array}$ & $\begin{array}{c}\text { Keputusan } \\
\text { Pembelian }\end{array}$ \\
\hline Pearson & 1 & $.843^{* *}$ \\
Correlation & & .000 \\
Sig. (2-tailed) & & 100 \\
$\mathrm{~N}$ & 100 & 1 \\
Pearson & $.843^{* *}$ & \\
Correlation & & \\
Sig. (2-tailed) & .000 & 100 \\
$\mathrm{~N}$ & 100 & \\
\hline
\end{tabular}

(Source: SPSS Program Output)

In the correlation above, the person correlation number of 0.843 indicates that correlation or relationship between sales promotion and purchasing decisions is very strong, because it is between 0.80-1.000.

\section{Simple Regression Analysis}

This analysis is intended to determine the influence between variable $\mathrm{X}$ (sales promotion) and variable Y (purchase decision).

The following is the result of a simple linear regression calculation:

Table 6 Simple Regression

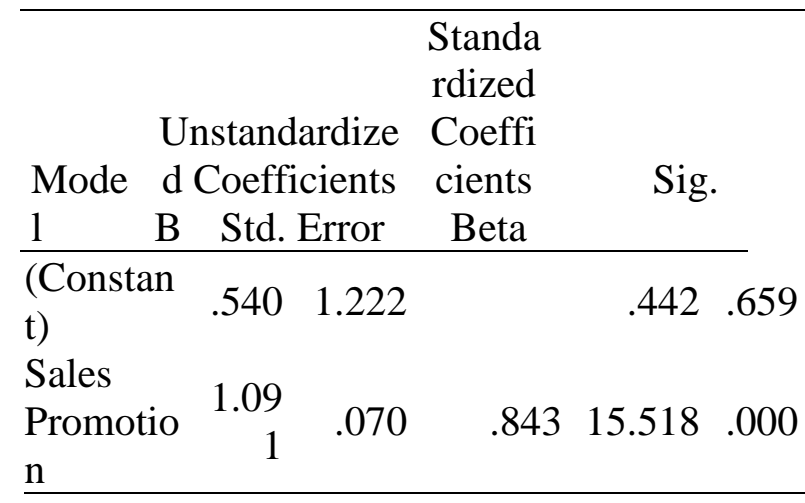

(Source: SPSS Program Output)

Regression analysis aims to forecast or estimate the value of dependent variables in relation to other variable values. In the table above, it appears that sales promotion affects purchasing decisions by 1,091. Thus simple linear regression is expressed in the equation:

$$
\begin{aligned}
Y^{\prime} & =a+b X \\
& =0.540+1.091 X
\end{aligned}
$$

Where:

$\mathrm{Y}=$ Purchase Decision

$\mathrm{a}=$ Constanta

$b=$ Regression Coefficient 
$\mathrm{X}=$ Variable Value

From the above result, the sales promotion regression coefficient of 1,091 states that if the sales promotion is binding by one unit, then the purchase decision increases by 1,091. From the results of the simple regression analysis above shows sales promotion has a positive influence on purchasing decisions.

\section{Analysis of Determination Coefficient}

Table 7 Summary

\begin{tabular}{lccc}
\hline R & $\begin{array}{c}\text { Adjusted R } \\
\text { Square }\end{array}$ & $\begin{array}{c}\text { Std. Error of the } \\
\text { Estimate }\end{array}$ \\
\hline 1 & Square & &
\end{tabular}

$\begin{array}{lll}.711 & .708 & 2.914\end{array}$

(Source: SPSS Program Output)

The determination coefficient aims to see the magnitude of the contribution for a free variable to its bound variable by looking at the magnitude of its total determination coefficient. Based on the table above the magnitude of the number R square (r2) is 0.711 . The number can be used to see the magnitude of sales promotion's influence on purchasing decisions by calculating the Coefficient of Determination (KD) by using the following:

$$
\begin{aligned}
& \mathrm{KD}=\mathrm{r} 2 \times 100 \% \\
& \mathrm{KD}=0.711 \times 100 \% \\
& \mathrm{KD}=71.1 \%
\end{aligned}
$$

The figure means that the influence of Sales Promotion on Purchasing Decisions is $71.1 \%$. The remaining $28.9 \%$ are other factors outside sales promotion.

\section{Research Hypothesis Test}

Simultaneous Hypothesis Test (f)

Table 8 Anova

\begin{tabular}{lccrrrr}
\hline & & & Mean & & \\
Model & & Sum of Squares & Df & Square & \multicolumn{1}{c}{ F } & Sig. \\
\hline 1 & Regression & 2045.439 & 1 & 2045.43 & 240.81 & \multirow{2}{*}{$000^{\mathrm{b}}$} \\
& & 832.401 & 98 & 8.494 & & \\
& Residual & 2877.840 & 99 & & & \\
& Total & & & &
\end{tabular}

(Source: SPSS Program Output) 
Volume 3 Issue 7 (June 2021) PP. 59-71

DOI 10.35631/AIJBAF.37005

From the table above, the calculated value of $F$ is 71.93 greater than the table $f$ of 3.94 with a significance of 0.00. It's below 0.05. Thus, ha accepted that the variable Sales Promotion has a positive and significant influence on the Purchase Decision.

\section{Partial Hypothesis Test (t)}

Table 9 Coefficient

\begin{tabular}{|c|c|c|c|c|c|}
\hline & $\begin{array}{l}\text { Unstanda } \\
\text { Coeffic }\end{array}$ & $\begin{array}{l}\text { rdized } \\
\text { ients } \\
\text { Std. }\end{array}$ & $\begin{array}{l}\text { Standardize } \\
\text { Coefficient }\end{array}$ & & \\
\hline Model & B & Error & Beta & $\mathrm{t}$ & Sig. \\
\hline (Constant & .540 & 1.222 & & .442 & .659 \\
\hline $\begin{array}{l}\text { Sales } \\
\text { Promotio }\end{array}$ & 1.091 & .070 & .843 & $\begin{array}{r}15.5 \\
18\end{array}$ & .000 \\
\hline
\end{tabular}

(Source: SPSS Program Output)

Based on the table above, it can be seen that the partial test result is known that the value of the variable sales promotion 0.00 is smaller than 0.05 so that the sales promotion partially affects the purchase decision with a beta value of $0.843(84.3 \%)$.

\section{Discussion of Research Results}

Based on the calculation of the number of questionnaire scores obtained questionnaire score obtained 1894 then the number is included in the continuum line. The continuum line used consists of four criteria (Excellent, Very Bad, Not Good). Based on the continuum area, the level of sales promotion Blibli.com lies at good intervals. This indicates that the level of sales promotion in Blibli.com is good. Based on the results of recapitulation of respondents' responses about sales promotion, it is known that the dimensions of the highest discounts

Based on the purchase decision made by customers Blibli.com based on the continuum area is in the area has been very good namely 1643 . Based on the results of the recapitulation of consumer responses regarding purchasing decisions in Blibli.com it is known that the highest post-election dimension is $21.54 \%$ with a score of 304 followed by the level of purchase decisions, the needs offered, alternative searches and the level of information search is at the lowest position of $18.07 \%$ with a score of 297 .

Based on the instrument test conducted it can be known that the questionnaire data obtained is valid because all the statements submitted have a value above 0.03 , the value of Cronbach alpha in the reliable instrument test where the value of Cronbach alpha obtained is 0.845 and 0.789 above 0.6 and each variable is normally 0.13 above 0.05 . Based on the results of a simple regression analysis conducted shows sales promotion has a positive influence on the purchase decision that if the sales promotion binds by one unit, then the purchase decision increases by 1,091. Based on the correlation analysis obtained that sales promotion has a very strong relationship because it is between 0.80-1.00. To determine how much influence sales promotion has on purchasing decisions, an analysis of the coefficient of determination can be obtained that sales promotion affects $71.1 \%$ of the purchase decision. Based on the hypothesis test conducted in the previous chapter it can be concluded that sales promotion positively and 
Volume 3 Issue 7 (June 2021) PP. 59-71

DOI 10.35631/AIJBAF.37005

significantly affects purchasing decisions where the significance value obtained is 0.00 below 0.05 , it is stated that Ha in this study was accepted and Ho rejected.

A person communicating has several reasons, including: seeking pleasure, seeking help, express ideas and opinions. Promotion can change consumer behavior and opinions about the product and encourage consumers to make product purchases. (Fam et al, 2019; Karthikeyan, 2013).

Sales promotion is an activity or material that serves as direct persuasion, that is offer added value to a product to sellers or consumers. Promotion is one of the determining factors for the success of a marketing program. promotion is a form of marketing communication. What is meant by marketing communication is an activity marketing that aims to spread information, influence, and remind the target market of the company and its products to be willing accept, buy, and be loyal to the products the company offers concerned. (Jallow \& Dastane, 2016; Daramola et al, 2014)

\section{Conclusions And Suggestions}

\section{Conclusion}

Based on descriptive analysis conducted obtained that consumer assessment of sales promotion conducted by Blibli.com is good. This indicates that the coupons, discounts and price packages that have been done by Blibli.com have been good.

Based on the descriptive analysis conducted obtained that the purchasing decisions made by consumers Blibli.com have been good. Based on testing with a simple linear regress analysis can be concluded that sales promotion affects $71.1 \%$ of purchasing decisions which means sales promotion has a large and positive influence on purchasing decisions made by consumers Blibli.com

\section{Suggestions}

Blibli.com should develop a Discount dimension which is the dimension that has the highest score and once the discount dimension can be executed optimally, it can then improve the other dimensions. For price plan dimensions that have the lowest score need to be improved through providing a more frequent and varied price plan.

Blibli.com should prioritize and improve the dimension of Alternative Search because it has the lowest score by conducting promotions on social media and print media so that consumers are aware of the latest information about Blibli.com thus making Blibli.com an alternative option in making purchases.

Sales Promotion is very concerned about consumer purchasing decisions, so Blibli.com is very necessary to manage and improve and add more sales promotion activities. If consumer purchasing decisions increase it will have a good impact on the sale of the company.

\section{References}

Amanah, D., \& Stephany, P. P. (2015). Pengaruh Promosi Penjualan (Sales Promotion) dan Belanja Hedonis (Hedonic Sopping) Terhadap Implusive Buying Produk Matahari Plaza Medan Fair. Jurnal Quanomic, 3(02), 10-18. 
Volume 3 Issue 7 (June 2021) PP. 59-71

DOI 10.35631/AIJBAF.37005

Basri, N. A. M. H., Ahmad, R., Anuar, F. I., \& Ismail, K. A. (2016). Effect of word of mouth communication on consumer purchase decision: Malay upscale restaurant. ProcediaSocial and Behavioral Sciences, 222, 324-331.

Basu Swastha, D. H., \& Irawan, M. B. A. (2008). Manajemen Pemasaran Modern. Yogyakarta: Liberty.

Batubara, A., \& Hidayat, R. (2019). Pengaruh Penetapan Harga dan Promosi terhadap Tingkat Penjualan Tiket pada PSA Mihin Lanka Airlines. Jurnal Ilman: Jurnal Ilmu Manajemen, 4(1).

Beins, B. C. (2017). Research method: A tool for life. Cambridge University Press

Daramola, G. C., Okafor, L. I., \& Bello, M. A. (2014). Sales promotion on consumer purchasing behaviour. International Journal of Business and Marketing Management, 2(1), 8-13.

Fam, K. S., Brito, P. Q., Gadekar, M., Richard, J. E., Jargal, U., \& Liu, W. (2019). Consumer attitude towards sales promotion techniques: a multi-country study. Asia Pacific Journal of Marketing and Logistics.

Ghozali, I. (2016). Aplikasi analisis Multivariete dengan program IBM SPSS 23 (edisi 8). Cetakan ke VIII. Semarang: Badan Penerbit Universitas Diponegoro, 96.

Jallow, H., \& Dastane, O. (2016). Effect of sales promotion schemes on purchase quantity: A study of Malaysian consumers. Management \& Marketing, 14(2).

Karthikeyan, B., \& Panchanatham, N. (2013). Impact of sales promotion techniques on consumers towards FMCG. International Research Journal of Business and Management, 8, 128-135.

Kotler, P. (2014). Marketing Management 12e. France: Edition Pearson Education.

Kotler, P., Keller, K. L., \& Manceau, D. (2012). Marketing Management. 14EEdition. NewJersey: Prentice Hall.

Kotler, P., \& Armstrong, G. (206). Marketing: an introduction (Vol. 6). Englewood Cliffs, NJ: Prentice-Hall

Neha, S., \& Manoj, V. (2013). Impact of sales promotion tools on consumer's purchase decision towards white good (refrigerator) at Durg and Bhilai Region of CG, India. Research Journal of Management Sciences ISSN, 2319, 1171.

Putri, B. R. T. (2017). Manajemen pemasaran. Denpasar: Universitas Udayana.

Yoebrilianti, A. (2014). Pengaruh Promosi Penjualan Terhadap Minat Beli Produk Fashion Dengan Gaya Hidup Sebagai Variabel Moderator (Studi Kasus Pada Jejaring Sosial).

Sugiyono, S. (2017). Metode penelitian kuantitatif dan kualitatif dan R\&D. Bandung: Alfabeta

Suharsimi, A. (2006). Prosedur penelitian suatu pendekatan praktik. Jakarta: Rineka Cipta, 120-123. 